\title{
Changes of Thyroid Hormonal Status in Organophosphate Exposure A systematic literature review
}

\author{
DANA TOMESCU1,2, CRISTIAN COBILINSCHI ${ }^{3 *}$, RADU CIPRIAN TINCU1,4, ALEXANDRA TOTAN5 , TIBERIU PAUL NEAGU6,7, \\ CAMELIA CRISTINA DIACONU ${ }^{8,9}$, MIRELA TIGLIS ${ }^{1,3}$, OVIDIU GABRIEL BRATU ${ }^{10,11}$, RADU ALEXANDRU MACOVEI ${ }^{1,4}$ \\ ${ }^{1}$ Carol Davila University of Medicine and Pharmacy, Clinical Department No. 14, $8^{\text {th }}$ Eroii Sanitari Str., 050474, Bucharest, Romania \\ 2Department of Anesthesiology and Intensive Care, Fundeni Clinical Institute, 258 \\ ${ }^{3}$ Department of Anesthesiology and Intensive Care, Emergency Clinical Hospital of Bucharest, $8^{\text {th }}$ Floreasca Av., 014461, Bucharest, \\ Romania \\ ${ }^{4}$ Department of Toxicology, Emergency Clinical Hospital of Bucharest, $8^{\text {th }}$ Floreasca Av., 014461, Bucharest, Romania \\ ${ }^{5}$ Carol Davila University of Medicine and Pharmacy, Faculty of Dental Medicine, Department of Biochemistry, $17-23^{\text {rd }}$ Calea \\ Plevnei, 010221, Bucharest, Romania \\ ${ }^{6}$ Department of Plastic Surgery and Reconstructive Microsurgery, Emergency Clinical Hospital of Bucharest, $8^{\text {th }}$ Floreasca Ave., \\ 014461, Bucharest, Romania \\ ${ }^{7}$ Carol Davila University of Medicine and Pharmacy, Clinical Department No. 11, $8^{\text {th }}$ Eroii Sanitari Str., 050474, Bucharest, \\ Romania \\ ${ }^{8}$ Department of Internal Medicine, Emergency Clinical Hospital of Bucharest, $8^{\text {th }}$ Floreasca Av., 014461, Bucharest, Romania \\ ${ }^{9}$ Carol Davila University of Medicine and Pharmacy, Clinical Department No. 5, $8^{\text {th }}$ Eroii Sanitari Str., 050474, Bucharest, Romania \\ ${ }^{10}$ Department of Urology, Carol Davila University Emergency Central Military Hospital, 88 ${ }^{\text {th }}$ Mircea Vulcanescu Str., 010825, \\ Bucharest, Romania \\ ${ }^{11}$ Carol Davila University of Medicine and Pharmacy, Clinical Department No. 3, $8^{\text {th }}$ Eroii Sanitari Str., 050474, Bucharest, Romania
}

\begin{abstract}
Organophosphates (OP) are widely used in both agriculture and household settings as pesticides. Human exposure is mainly due to residues in food or living environment and the main mechanism of OP toxicityare the acetylcholinesterase (AChE) inhibition. Acute poisoning is associated with a high rate of mortality due to parasympathetic overstimulation. In long-term exposure, $O P$ are linked to systemic damage occurrence like nervous, hepatic or renal dysfunction. These compounds are considered as potential endocrine disrupters, causing significant hormonal imbalance targeting the adrenals or thyroid glands. The aim of this article is to review current data in the literature regarding effects of both acute and chronic OP exposure on thyroid hormonal status.
\end{abstract}

Keywords: thyroid hormones; organophosphates; poisoning.

Organophosphate (OP) compounds are chemicals that have a great range of applications in both industrial and domestic areas, acting as pesticides, nerve agents or antiparasitic agents [1]. OPs were first synthetized in early 1800 s and used as chemical warfare agents; it was only around 1940s that people began using them as pesticides, as originally intended [2]. OPs contain a phosphorus atom and a characteristic phosphoryl bond [3] .

The risk of toxicity is highly increased by mishandling the products in household or occupational activities or it can rarely be a result of military events since OP can be used in chemical weapons' production [4].

Manipulating OP for pest control in agriculture is the most frequent cause of human exposure and intoxication, leading to an estimated 3 million cases/year $[5,6]$. Their wide accessibility facilitated their use as suicidal agents, causing approximately 300,000 deaths per year [7], despite several restriction regulations in the United States and Europe.

OP poisoning can occur by cutaneous, respiratory or oral exposure to the agent. The accumulation of acetylcholine and hyperstimulation of its receptors at the neuromuscular junction and in the nervous system leads to the acute cholinergic crisis [8]. Early signs include bronchorrhoea, bronchospasm, miosis, salivation, defecation, urination, and hypotension [8]. Besides, muscle weakness and fasciculations as well as seizures, coma, and respiratory failure can occur in the acute phase of the exposure. Respiratory distress can be a part of the intermediate syndrome and occur hours later from the poisoning, involving a downregulation of nicotinic acetylcholine receptors. In the recovery phase, a peripheral neuropathy can develop, either motor or sensory [8].

Pesticides, with chlorpyrifos (CPF) being the most largely utilized (fig. 1), have been incriminated in various neuropsychological effects (speech, memory and attention, coordination) caused by chronic exposure but also in endocrinological changes $[9,10]$. The latter were suggested in pituitary-targeted gland hormones naming the compounds as endocrine disrupting chemicals (EDC) [11]. EDCs are responsible for hormonal imbalance, interfering with hormone receptors, their bioavailability or metabolism [12,13].

The mechanism of action in organophosphates is the inhibition of acetylcholinesterase (AChE) by phosphorylating its serine hydroxyl group so that acetylcholine (AChE) accumulates at neuromuscular junctions [14]. This excess

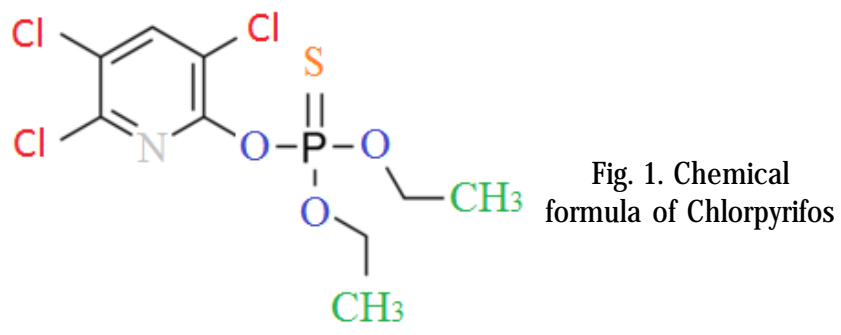


AChE conducts to muscarinic and nicotinic receptor over stimulation with varied clinical manifestations, affecting cardiac, respiratory, renal or neurological functions, leading to organ failure $[15,16]$.

Although the main action mechanism of OPs is acetylcholinesterase inhibition, induction of oxidative stress has also been incriminated for their adverse reactions [16]

Effects of organophosphates on different systems such as cardiovascular, nervous, renal or respiratory functions have been thoroughly studied, most of the time, multiple organ failure being the final result [17-20]. However, data concerning outcomes of exposure on the endocrine system is scarce and no recent study has been published on this topic.

The aim of this review is to collect existing data in the literature regarding the effects of organophosphate exposure on thyroid hormonal status.

\section{Thyroid hormones in critical illness}

Thyroid hormones play a major role in differentiation, growth and maintaining metabolic homeostasis. They are vital for the normal function of nearly all tissues, with major implications in oxygen consumption and metabolic rate [21].

Thyroid function test results may be altered in nonthyroidal, critical illnesses through a number of mechanisms such as the inhibition of thyroxine uptake by the hepatocytes and limiting its conversion to triiodothyronine in the periphery. In addition, circulating cytokines can influence hormone levels. These alterations in thyroid hormone levels are called sick euthyroid syndrome [22, 23].

Changes that concern the hypothalamic-pituitarythyroid (HPT) axis occur in various illnesses and are usually associated with low levels of free triiodothyronine (T3) thus being called as the low T3 syndrome [24-27]. Sick patients with low serum T3 are considered as clinically euthyroid, hence the above-mentioned euthyroid sick syndrome. This refers to changes in thyroid hormone concentrations caused by an acute or chronic illness and not due to an intrinsic abnormality in thyroid function. However, it is not yet certain if these hormonal imbalances appear as a necessity to handle stress and lower the metabolic rate, hence helping the patient overcome his condition [23].

Alterations in hormone secretion can be a result of severe illness, physical trauma, or physiologic stress but also caused by a large number of drugs and chemical compounds, among which organophosphates are cited [22].

Several studies indicate there is a cholinergic regulation of thyrotropin (TSH) secretion through somatostatin. Dopamine stimulates the release of somatostatin from the median eminence of the hypothalamus where nicotine receptors are located and increases its portal blood concentration, TRH, and TSH secretion rates [22].

In the sick euthyroid syndrome, the most frequent exhibited change is a decrease in T3 values that represents the most constant finding. Some patients may show variations of TSH or free thyroxine (T4) during a critical illness [24]. In the recovery period, TSH usually increases, sometimes above the normal laboratory range. In admitted patients, T4 levels might be high, normal or low [27].

\section{Organophosphate exposure and thyroid hormonal status}

Endocrinological changes due to organophosphate exposure, whether acute or on long-term, are not yet clearly defined in the literature. Observations and results in published studies are mostly based on laboratory animal work, namely different generations of mice.

The study of De Angelis et al. [11] published in 2009 aimed to examine both the short- and long-term effects of chlorpyrifos on thyroid and adrenal glands in CD1 mice during gestational and postnatal phases. Results showed that CPF dose levels below those inhibiting brain AchE can induce alterations in the thyroid, both in hormone secretion and histopathological aspect. Modified T4 levels were observed respectively a reduced serum T4 level especially in male mice together with a significant increase in the height of thyroid follicular epithelium. Moreover, a large number of necrotic cells were present in the thyroid follicles' lumens. These histopathological findings suggest there is a dose-dependent decreased follicular density.

The study of De Angelis is in agreement with the work of Jeong et al. [28] that found decreased T4 levels and vacuolation or necrosis of thyroid follicular epithelial cells in exposed male rats.

Another study, the one of Meeker et al. [29] published in 2006 suggested a thyreostatic effect of Chlorpyrifos, that is a negative association between urinary levels of CPF and T4 levels and a positive association with TSH.

A more recent study published in 2015 by Dutta et al. [7] aimed to assess alterations in pituitary target gland hormones at admission, at discharge and at three months following acute OP exposure. After applying the exclusion criteria, eight males and six females were enrolled in the study. Results showed that serum TSH was lower at the time of admission compared to TSH at 3 months of followup.T3 and T4 levels did not differ significantly at baseline from values at 3 months.

Mean levels of T3 and TSH were low normal and normalized at discharge and at three months check-up. These modifications in thyroid function are similar to those observed during critical illness, specifically low T3, low or low normal T4 and normal to low normal TSH. However, in the study of Dutta et al., the mean serum T4 remained normal throughout the study period [7]. Mean TSH values correlated to acetyl cholinesterase, which predicts the severity of poisoning.

As in critically ill, in OP poisoning there is a cytokine mediated suppression adding to a cholinergic mediated rise in somatostatin that contributes to the suppression of TSH.

A prospective study conducted by Satar et al. [22] set to determine possible endocrine effects of the treatment of organophosphate poisoning. Patients with exposure to an organophosphate compound, signs and symptoms of cholinergic syndrome, and decreased plasma cholinesterase were included. Hormone levels were tested before and after treatment with atropine and pralidoxime.

The decrease in TSH levels was not statistically significant but FT4 levels increased following treatment. Six patients were diagnosed on admission with sick euthyroid syndrome and eleven patients who were euthyroid on admission developed sick euthyroid syndrome following treatment (low T3 levels) [22].

In the study of Güven et al. [23] that evaluated endocrinological changes in acute organophosphate poisoning, they found that seven (31.8\%) patients had sick euthyroid syndrome, including suppression of TSH, T4 and T3, which resolved after resolution of poisoning.

A research published in 2016 by Piccoli etal. [30] aimed to measure serum thyroid hormone levels in an agricultural population. A cross-sectional study was therefore conducted, including 275 male and female workers. Results suggested that both acute and chronic occupational exposure to pesticides may increase TSH levels and 
decrease FT4, especially in males. Moreover, a prolonged contact to such compounds can lead to thyroid disorders such as hypothyroidism.

\section{Conclusions}

The data in the present article suggests that both acute and chronic exposure to organophosphate compounds may affect thyroid function, expressed both in hormone secretion and histopathological changes. OP poisoning causes a decrease in circulating levels of thyroid hormones with hypothyroid-like effects and consequently an increase in TSH.

Given the wide use of pesticides in agriculture and the potential risk of human exposure, future research should focus on evaluating long-term effects of OPs on thyroid function conducting longitudinal research studies with repeated measures of exposures and outcomes, together with preventive rules.

\section{References}

1.*** EPA U., OF PESTICIDE PROGRAMS 0., Recognition and Management of Pesticide Poisonings: Sixth Edition: 2013: Chapter 5 Organophosphates. [cited 2018 Feb 12]; Available from:https:// www.epa.gov/sites/production/files/documents/rmpp_ 6thed_ch5_ organophosphates.pdf

2.PETROIANU, G.A., Pharmazie., 65, nr. 4, 2010, p. 306-311

3. ${ }^{* * *}$ Committee on Toxicity of Chemicals in Food, Consumer Products and the Environment ORGANOPHOSPHATES. [cited 2018 Feb 12]; Available from: https://cot.food.gov.uk/sites/default/files/cot/ opchap.pdf

4.GUPTA, R.C., InToxicol., 2006, p. 5

5.DHARMANI, C., J AGA, K., Rev. Environ. Health., 20, nr. 3, 2005, p. 215 6.RAZWIEDANI, L.L., RAUTENBACH, P.G.D., Environ. Health Insights, 11,2017

7.DUTTA, P., KAMATH, S.S., BHALLA, A., SHAH, V.N., SRINIVASAN, A., GUPTA, P., SINGH, S., Indian J. Endocrinol. Metab., 19, nr. 1, 2015, p. 116

8.BLAIN, P.G., BMJ Clin. Evid., 2011

9.ZAREI, M.H., SOODI, M., QASEMIAN LEMRASKI, M., JAFARZADEH,

E., TAHA, M.F., Environ. Toxicol., 31, nr. 11, 2016, p. 1510

10.LEE, Y.S., LEWIS, J.A., IPPOLITO, D.L., HUSSAINZADA, N., LEIN, P.j., JACKSON, D.A., STALLINGS, J.D., Toxicol., 340, 2016, p. 53

11.DE ANGELIS, S., TASSINARI, R., MARANGHI, F., EUSEPI, A., DI VIRGILIO, A., CHIAROTTI, F., RICCERI, L., PESCIOLINI, A.V., GILARDI, E., MORACCI, G., CALAMANDREI, G., Toxicol. Sci., 108, nr. 2, 2009, p. 311
12.VENTURA, C., NIETO, M.R., BOURGUIGNON, N., LUX-LANTOS, V., RODRIGUEZ, H., CAO, G., RANDI, A., COCCA, C., NUNEZ, M., J. Steroid Biochem. Mol. Biol., 156, 2016, p. 1

13.COCOLOS, A.M., DUMITRU, N., PETROVA, E.N., COCOLOS, I., TIGLIS, M., DRAGOMIRESCU, R.F., OLARU, M., DUMITRU, A., GHEMIGIAN, A.M., Rev. Chim. (Bucuresti), 69, no. 1, 2018, p. 134 14.COLOVIC, M.B., KRSTIC, D.Z., LAZAREVIC-PASTI, T.D., BONDZIC, A.M., VASIC, V.M., Curr. Neuropharmacol., 11, nr. 3, 2013, p. 315

15.CHECHERITA, I.A., DAVID, C., DIACONU, V., CIOCALTEU, A., LASCAR, I., Rom. J. Morphol. Embryol., 52, nr. 3 Suppl, 2011, p. 1047

16.RANJ BAR, A.K., PASALAR, P., ABDOLLAHI, M., Human Exp. Toxicol., 21, nr. 4, 2002, p. 179

17.NECHITA, A.M., PITURU, S., RADULESCU, D., PERIDE, I., NEGREANU, L., NICULAE, A., FERECHIDE, D., CHECHERITA, I.A., SINESCU, R.D., Farmacia, 64, nr. 3, 2016, p. 348

18.CHECHERITA, I.A., DAVID, C., CIOCALTEU, A., LASCAR, I., Chirurgia (Bucur.), 104, nr. 5, 2009, p. 525

19.NICULAE, A., JINGA, M.A., CIOCALTEU, A., LASCAR, I., JINGA, V., CHECHERITA, I.A., Rom. J. Morphol. Embryol., 52, nr. 3, 2011, p. 863 20.PERIDE, I., CHECHERITA, I.A., CIOCALTEU, A., LASCAR, I., Chirurgia (Bucur.), 106, nr. 1, 2011, p. 83

21.YEN, P., M., Physiol. Rev., 81, nr. 3, 2001, p. 1097

22.SATAR, S., SATAR, D., KIRIM, S., LEVENTERLER, H., Am. J. Ther., 12, nr. 3, 2005, p. 238

23.GUVEN, M., BAYRAM, F., UNLUHIZARCI, K., KELESTIMUR, F., Human Exp. Toxicol., 18, nr. 10, 1999, p. 598

24.WARNER, M.H., BECKETT, G.J., J. Endocrinol., 205, nr. 1, 2010, p. 1

25.BARBU, C.G., FLORIN, A.N., NEAMTU, M.C., AVRAMESCU, E.T., TERZEA, D.A., MIRON, A.D., Rom. J. Morphol. Embryol., 56, nr. 2, 2015, p. 527

26.NICULESCU, D.A., DUSCEAC, R., GALOIU, S.A., CAPATINA, C.A., POIANA, C., Endocr. Pract., 22, nr. 8, 2016, p. 974

27.SPENCER, C., EIGEN, A., SHEN, D., DUDA, M., QUALLS, S., WEISS, S., NICOLOFF, J., Cl. Chem., 33, nr. 8, 1987, p. 1391

28.J EONG, S.H., KIM, B.Y., KANG, H.G., KU, H.O., CHO, J.H., Toxicol., 220, nr. 2-3, 2006, p. 189

29.MEEKER, J., D., BARR, D., B., HAUSER, R., Reprod. Toxicol., 22, nr. 3, 2006, p. 437

30.PICCOLI, C., CREMONESE, C., KOIFMAN, R.J ., KOIFMAN, S., FREIRE, C., Environ. Res., 151, 2016, p. 389

Manuscript received: 21.09 .2018 